ARTICLE

DOI: $10.1057 /$ s41599-018-0106-8

\title{
Gothic fairy-tales and Deleuzian desire
}

Holly Hirst ${ }^{1}$

\begin{abstract}
This article seeks to address the 'identity' of the 'gothic fairy-tale' through an investigation of Rana Dasgupta's Tokyo Cancelled (2005), a collection of globally oriented short stories that straddle the line between the gothic and the fairy-tale. The argument provides a close analysis of a number of the tales within Dasgupta's collection to highlight the parity between the gothic and the fairy-tale at the level of both plot and character. Moving beyond the well-documented case of how a writer and critic such as Angela Carter exposes the latent horror of the fairy-tale, the argument seeks to explore the juncture of the gothic and the fairy-tale represented in Tokyo Cancelled and, in doing so, illustrate the ways in which fairy-tales and the gothic both depend upon certain configurations of desire while questioning the primacy of 'horror' and 'terror' to definitions of the gothic mode. While highlighting the similarities between fairy-tale and gothic forms, this article also posits the existence of 'fairytale' and 'gothic' sensibilities that are fundamentally different from one another, a difference that is founded ultimately upon the question of desire. Employing Gilles Deleuze and Felix Guattari's concept of productive desire, a model that opposes that of 'desire-as-fantasy' and 'desire-as-lack', which are associated with the fairy-tale and explicitly rejected in Tokyo Cancelled, the article posits a particularly gothic conception of desire. This 'gothic desire' is central both to the gothic mode generally and to the 'gothic fairy-tale' more particularly. Rana Dasgupta's work acts as an illustration of this conception of the 'gothic fairy-tale,' one which moves away from an emphasis on terror, horror, transgression and fear to focus instead on a widely differing creative project and a conception of desire as definitional to form.
\end{abstract}

\footnotetext{
${ }^{1}$ Manchester Metropolitan University, Manchester, UK. Correspondence and requests for materials should be addressed to H.H. (email: h.hirst@mmu.ac.uk)
} 


\section{Introduction}

he gothic is notoriously difficult to define but all of our definitions-from H. P. Lovecraft's investigation of 'Supernatural Horror in Literature' (2011, pp 521-591) ${ }^{1}$ to Devandra Varma's early scholarship on the 'Gothic Flame' (1957) to the influential work of modern critics Punter (1996) and Botting's(1996) on the gothic or Chris Baldick's working tropebased definition in the Oxford Book of Gothic Tales (1992)-dwell on its darkness, its transgression, its excess and its celebration or exploration of fear. When we think, then, of a gothic fairy-tale, what comes to mind are Angela Carter's blood and passionsoaked re-imaginings in The Bloody Chamber (1979), dark filmic adaptations such as Snow White: A Tale of Terror (1997) and The Curse of Sleeping Beauty (2016) or the horrific details of some of the original versions themselves: rape (Sleeping Beauty), cannibalism (Hansel and Gretel) and self-mutilation (Cinderella). Rana Dasgupta's Tokyo Cancelled, however, offers a different vision of the gothic fairy-tale, one that, while including elements of violence, moral transgression and dark sexual desires, draws attention to the importance of the question of the desire to both the gothic and the fairy-tale. His modern gothic fairy-tales show that the heart of both the fairy-tale and the gothic is not only dark but 'desiring'.

The frame narrative of Tokyo Cancelled introduces us to a group of story-telling strangers from diverse undisclosed locations who, while stranded in the neutral space of an airport, set out to fill the silence and ultimately bridge the distance between them with a range of fantastic tales. By including a global outlook, and by reflecting diverse folk traditions in tales set in urban locations across the globe, he seeks to create 'a mythology of the twenty-first century city' (Dasgupta, 2005a, p. 2). Tokyo Cancelled actively engages with fairy-tales, folktales and mythological traditions from many world cultures, from the Hindu epic Ramayana to the Western European Rapunzel. ${ }^{2}$ These are not simply modern fairy-tales, however, since they engage equally extensively with the gothic mode. As Marina Warner argues, fairy-tales 'do not leave open prickly possibilities, or enter unnegotiated areas of the unknown' (1994, p. xvi) and, as Derek Brewer emphasises, their endings, if not happy, are yet 'closed' (1998). Dasgupta's tales, while carrying many of the markers of the fairy-tale are replete with uncomfortable and uncanny depictions that trace liminal boundaries, most notably in the paradigmatically uncanny of an animated doll in 'The Doll'. ${ }^{3}$ Endings are inconclusive or disturbing, most poignantly so in the live burial depicted in 'The Flyover'. Characters constantly confront the unfamiliar, the unknown and the inexpressible as they navigate worlds that they cannot understand; 'The House of the Frankfurt Mapmaker' is the clearest example of this with its displaced mute heroine trapped in a house and a world she knows nothing of. They are not 'simply' fairy-tales: a gothic sensibility is evident. It is the gothic that leaves open these unsettling spaces and moves beyond the 'heroic optimism' (Warner, 1994, p. xvi) that remakes the world in the image of desire' (Warner, 1994, p. xii). In engaging with both fairy-tale and gothic 'sensibilities', Dasgupta highlights the similarities and differences between them, allowing an investigation of the ways in which a fairy-tale may be (or become) gothic. Central to this discussion, moving beyond an exclusive concentration on the apparatus of terror and transgression associated with the gothic mode, is the issue of desire. What we find in Dasgupta is a triumph of a characteristically gothic form of desire that contrasts with the 'wish-fulfilling fantasies' (Bettelheim, 1976, p. 85) that lie at the heart of the fairy-tale. This paper will use Deleuze and Guattari's (1987) conception of 'positive desire,' contrasted with psychoanalytic conceptions of 'desire-as-lack' and 'desire-as-fantasy', to articulate the positive desire that resides at the heart of Dasgupta's tales and which he uses to create a new model for the gothic fairy-tale.

\section{Tokyo Cancelled and the fairy-tale}

Before investigating the nature of the gothic fairy-tale and how this manifests in Tokyo Cancelled, it is necessary to clarify my use of 'fairy-tale' by specifying both how the term 'fairy-tale' is being utilised and applied and articulating its usage in specific reference to Dasgupta's tales. The fairy-tale, like the gothic, is notoriously difficult to define, and there is a significant body of secondary literature dedicated to the task of such definition. It is not within the scope of this article to provide a thoroughly systematic definition of either the fairy-tale or the gothic. Having, however, offered a working definition of the term 'fairy-tale', as applied in this paper, I will show how the gothic as a mode (or as I term it in this article a 'sensibility') manifests in the gothic fairy-tale and specifically in Dasgupta's tales. With Warner (1994), I use 'fairy-tale' as a relatively loose term for a range of folkloric productions that may elsewhere be more divisively defined as 'wonder-tales,' 'folk-tales,' 'myths' and other regional denominations. The defining features of this broad category of the 'fairy-tale' used in this article have been taken from a variety of sources including, most influentially, the work of Vladimir Propp, Marina Warner, Hilda Ellis Davidson, Derek Brewer and Anna Chaudri.

In terms of the fairy-tale, there are a number of definitional qualities that appear widely across critical definitions and which we can trace in Dasgupta's stories. Each of the critics referenced above refers to the 'oral/literary question' (Davidson and Chaudri, 2003, p. 11) in different ways yet agree on the basic principle that the fairy-tale is connected to oral tradition. ${ }^{4}$ The tales within Tokyo Cancelled are, of course, presented as orally transmitted in a manner (strangers brought together by chance or force majeure and seeking entertainment) that Dasgupta deliberately uses to recreate a 'sense of the medieval cycle' (Dasgupta, 2005a, p. 3) such as The Decameron or The Canterbury Tales. In terms of function, the fairy-tale, Propp, in The Theory and History of Folklore (1984) tells us, often performs the task of reflecting cultural values and of serving a didactic (often moral) purpose as well as representing a form of entertainment. This moral might not be not what we expect, as in the tales of giant killer and professional thief Jack. As Brewer notes, 'the fairy tale, and folktale in general, are, like most children, not much impressed by the socially dynamic middle-class notions of bettering oneself by hard work, honest dealing and moral integrity.' (Brewer, 1988, pp. 50-51). However, as he goes on to argue, this does not mean that there is not a form of moral attached. Tales containing characters as little commendable to conventional bourgeois morality as Jack are often a paean to 'persistence', the 'self-confidence to take a chance' or 'kindness to others' (Brewer, 1988, p. 51) or offer,at the least, the moral that a reward awaits if one does not shy away from the hazardous struggles without which one can never achieve true identity.' (Bettelheim, 1976, p. 26) This emphasis on 'values' and an over-arching and sometimes overt 'moral' is reflected in Dasgupta's tales. 'The Shop on Madison Avenue,' for example, contains a summary warning that is borne out by the unfortunate consequences of the text: 'never become greedy...it could deprive you of everything you have' (2005b, p. 139). As Warner (1994) notes, fairy-tales refer frequently to common themes such as love, wisdom and (true) riches. Brewer (1988) makes stronger, and somewhat more reductive, claims, namely, that fairy-tales always reflect the 'family drama': the transitional period from child to adult, in which ones moves away from the 
family of origin into a relationship with a peer, which results, in turn, in the creation of a new family. Without fully accepting Brewer's definition, it is clear that such patterns emerge in fairytales (Rapunzel's move away from the control of a restrictive maternal figure to an adult peer relationship with the Prince); in turn, these are equally reflected in Dasgupta's tales along with the themes picked out by Warner. 'The Memory Editor,' e.g., explicitly discusses the meaning of 'true riches' and the concept of wisdom while playing out the 'family drama' of Thomas: his rejection by his family and his slow development of external relationships and self-worth. Similarly, as noted by most critics, fairy-tales contain common plot and character tropes such as the rescued maiden, the cunning idiot, changelings, revelatory dreams, the tyrant's castle, the quest, the inanimate animated and metamorphosis, ${ }^{5}$ all of which feature in Dasgupta's work. In addition to this, individual fairy-tales are also explicitly referenced, for example, the Ramayana in 'The Billionaire's Sleep', while stories such as 'The Changeling' offer a retelling or reimagining of a common fairy-tale trope, namely, the changeling child. None of these fairy-tale elements, it must be noted, exclude the possibility of a gothic sensibility and, as I will discuss later, many tropes, themes and even character types may commonly be found in gothic works.

Fairy-tales often revert to the marvellous or the 'supernatural', and it is in the usage and representation of these elements that we begin to see a marked contrast with the gothic. The world of the fairy-tale appears to reflect the social realities of its producers, but 'neither the teller nor the listener treats it as reality' (Propp, 1984, p. 19). In other words, especially at the oral stage in fairy-tale history and at the time of the first literary versions, the 'world' of the fairy-tale and its social conditions are recognisable, yet it is a world of wonder where magic is unquestioned. Tokyo Cancelled similarly presents a 'contemporary' recognisable world, in which the magical elements of the stories (bodily transformations, magic birds, changelings, curses, magic) are represented as occurring in the world without question. The fairy-tale and the gothic share an interest in the 'marvellous' (the supernatural) but the gothic differs in its emphasis on darkness, uncertainty, transgression and fear. The 'creatures' and supernatural manifestations of the gothic are usually questioned or doubted within the narrative, a factor that is largely absent from Tokyo Cancelled, thereby aligning the tales with the gothic fairytale rather than the 'simply' gothic. To say that fear is a key modality of the representation of the supernatural in the gothic is not to suggest the absence of fear or horror from the fairy-tale. Angela Carter's provocative and evocative retellings of fairy-tales in The Bloody Chamber (1979), as she claims, extract 'the latent content of the traditional stories' (2006, p. viii). This latent content, she appears to suggest, is perverse sexuality, blood, death, violence, violation and coercion. What is perhaps most important in Carter's claim is the latent nature of this content, contained within the closed 'heroic[ally] optimistic' (Warner, 1994, p. xvi) narrative of the tale. In the fairy-tale, these features exist, but in the gothic, these unsettling possibilities, these deviances, these transgressions are gleefully explored, even if ultimately rejected. This article is not concerned with the underlying horror of the fairy-tale (its witches, spells, deaths, imprisonments, cannibals, hideous punishments, physical disfigurements and moralizing through fear), which is an area that has already been explored both fictionally and critically in great depth. Though these elements appear in Tokyo Cancelled (malignant magical tricksters, mutilation, murder, monstrous deformities are but a few of the examples) they are not the focus of this paper. Rather, it is the desire that lies at the heart of both forms that this article seeks both to explore and differentiate and which I will discuss at greater length below.

\section{Tokyo Cancelled and fairy-tales in the gothic mode}

The gothic element in Tokyo Cancelled is initially harder to trace than the fairy-tale elements. This is in part due to the lack of direct references to gothic texts or an overtly stated or suggested attempt at rewriting or re-imagining a specific 'canonical' gothic text. However, the fairy-tale and the gothic are not as disparate as we might assume, particularly in terms of structure and plot, and many of the tales teeter on the brink of the gothic, with only a change of 'sensibility' needed to tip their almost identical plots into the other mode. By investigating the framework of 'The Billionaire's Sleep', for example, it becomes clear that this apparently fairy-tale narrative is deeply engaged with an overlapping gothic aesthetic. In 'The Billionaire's Sleep' Rajiv, the titular billionaire, cannot sleep, a condition which has led to his infertility. In a classic fairy-tale trope, the childless parents, Rajiv and Mira, long for children. ${ }^{6}$ In the modern world of the text, however, they do not rely on hope or magic, but on human cloning. The process is successful and twins are born. The boy, Imran, is hideously ugly, 'a shrunken, misshapen boy with an outsized head that had the pointed shape of a cow's' (2005b, p. 64). He is rejected by his father, who sends him away to be cared for by a poor Muslim family. The girl, Sapna, is retained and adored by both parents until she starts to manifest disturbing powers upon entering adolescence. Her sleep, which has always had restorative properties, creates a 'furore of fertility' (2005b, p. 68) - inanimate objects burst into flowering life around her and her parents conceive a child. The government fears the creative/ destructive possibilities of her 'power' and so her father confines her to a tower to which he is her sole visitor. Her mother's love turns to disgusted denial and her new brother despises her. Meanwhile, Imran has become a television star famed for his portrayal of the demon Ravana in a TV production of the Ramayana. Through a series of coincidences, they both fall in love with each other 'in absentia' as Sapna falls for the demon that her brother portrays on television and Imran hears her music, which opens up to him 'what he had been longing for all his life' (2005b, p. 64). He attempts to steal her from the tower but they are caught and locked in a lunatic asylum. They escape when the asylum is destroyed by the plants that grow during Sapna's magical sleep. After Imran kills the murderous younger brother in an act of mixed self-defence and vengeance for his attack on Sapna, they are last seen energetically making love in an abandoned building. As this synopsis suggests, there are clear references to Rapunzel (the tower, the parents longing for a child), Sleeping Beauty (magical sleep, parents longing for a child) and the Ramayana (separated lovers, abduction of the bride) but the basic structure of the story also conforms to a gothic paradigm as I will demonstrate below.

Anne Williams' schematic of what she terms 'female gothic plots' in Art of Darkness is over-generalising, but it flags the similarity of the plot of many gothic narratives to that of fairytales. For Williams, the 'ingredients' of a 'female gothic' narrative are as follows: a heroine, a home of initiation, a happily ever after, a responsibility, a suitor, a second suitor, a male antagonist, a female antagonist, a confidante (1995, p. 256). The table below efficiently represents how this schema can be used to map out many fairy-tales and gothic texts and how it applies to 'The Billionaire's Sleep' in particular. I have also included four extra categories of similarity between the texts to highlight the degree to which the forms overlap-imprisonment in a tower/castle, loss of parents (heroine), vicissitudes of the hero and 'salvation' of the hero. This comparison effectively represents the overlap between gothic and fairy-tale plots, highlighting the liminal space between the 'gothic' and the 'fairy-tale' that the tales may occupy, and the subsequent impossibility of classification based on elements of plot alone (Table 1$)^{7}$ 
Table 1 Features of Female Gothic narratives (identified by Anne Williams with the addition of four final categories) demonstrated across a Gothic novel, a fairy-tale and a tale from Tokyo Cancelled

\begin{tabular}{|c|c|c|c|}
\hline & $\begin{array}{l}\text { Ann Radcliffe Mysteries of Udolpho } \\
\text { (1796) }\end{array}$ & $\begin{array}{l}\text { Brothers Grimm Rapunzel } \\
\text { (1812) }\end{array}$ & $\begin{array}{l}\text { Rana Dasgupta The Billionaire's Sleep } \\
\text { (2005a) }\end{array}$ \\
\hline Heroine & Emily St. Aubert & Rapunzel & Sapna \\
\hline Home of initiation & La Valleé & Family Cottage & Family home in Delhi \\
\hline Responsibility & Madame Montoni & Parents & $\begin{array}{l}\text { Need to control destructive possibilities of } \\
\text { powers }\end{array}$ \\
\hline Male antagonist & Montoni & - & $\begin{array}{l}\text { Unnamed younger brother (Rajiv- } \\
\text { imprisons her) }\end{array}$ \\
\hline Female antagonist & Madame Montoni Laurentini & Dame Gothel/ Enchantress & Mira \\
\hline Confidante & Annette (servant) & - & (Rajiv-her only visitor and friend) \\
\hline Imprisonment in castle/tower & Castle of Udolpho & $\begin{array}{l}\text { Dame Gothel's tower with no } \\
\text { doors. }\end{array}$ & Sealed tower \\
\hline Loss of parents (heroine) & Death of parents & Given away by parents & Rejected by mother \\
\hline
\end{tabular}

It is important to acknowledge that not all gothic narratives, fairy-tales or stories in Tokyo Cancelled follow the scheme detailed above. In Tokyo Cancelled itself Dasgupta engages with many other story patterns or elements common to both the gothic and the fairy-tale. A brief survey of the collection encounters the following tropes:

- The tyrannical husband and house with hidden rooms ('The House of the Frankfurt Mapmaker' [D], ${ }^{8}$ Blue Beard ${ }^{9}$ [FT] and Charlotte Bronte's Jane Eyre [G]).

- 'Magical' transformation ('The Store on Madison Avenue' and 'The Changeling' [D], The Frog Prince [FT] or Beauty and the Beast [FT], Franz Kafka's Metamorphosis [1915 G]).

- The inanimate animated ('The Doll' [D], Carlo Collodi's Pinocchio [1883 FT], Mary Shelley's Frankenstein [1818 - G]).

- Separated lovers ('The Rendezvous in Istanbul' and 'The Lucky Ear Cleaner' [D], Rapunzel and Sleeping Beauty [FT], Radcliffe's The Italian [1797 G])

- The stolen child/giving away of the firstborn ('The Bargain in the Dungeon' [D] offers an updated version in which the heroine, Katya, sells her fertility, Rumpelstiltskin [FT], Radcliffe's Romance of the Forest [1791 G]).

- The discovery, and murder of, the unknown father/paternal figure ('The Flyover' [D], Sophocles Oedipus Rex [429BC FT], Romance of the Forest [G]).

Despite the narrative similarities between fairy-tales and gothic narratives, it is not my wish to suggest that they are effectively the same. There is a fairy-tale and a gothic sensibility to be applied to these apparently similar plot devices. ${ }^{10}$ A brief investigation of the tropes of magical transformation and of the animate inanimate exemplifies such a distinction and shows how Dasgupta consciously engages with both sensibilities. In Fantastic Metamorphoses, Warner (2002) argues that transformation is a common trope in the fairy-tale and appears in three forms. The first is that of the shape-changer, a trope illustrated by the mythic figure of Zeus who takes on many different animal and non-animate forms in order to seduce what appears to be half the female population of Ancient Greece. The second variant is that of the definitive change to a form that 'more fully expresses them and perfects them than their first form' $(2002$, p. 4), which Warner suggests is illustrated by the tale of Echo and Narcissus recorded by Virgil. The final variant is that of the temporary change prompted by outside force as punishment or impediment, which we find, e.g., in The Frog Prince. What unifies these three types of magical transformation is the idea of a complete transformation-a 'become'. The 'before' and 'after' (however many times the change occurs) remain separate and complete in themselves-the frog prince retains nothing of the frog when he returns to a princely form. In contrast, in tales of gothic transformation (such as The Metamorphosis by Franz Kafka, werewolf narratives or The Beetle by Richard Marsh) the key focus is not a completed transformation but a process, a confusion of forms and identities or a mutation-a 'becoming'. In The Beetle, for example, the creature is described as neither human nor animal, male nor female, large nor small (2007, p. 108-111). In The Metamorphosis and werewolf narratives, the differentiation between human and animal is increasingly blurred, not only in terms of physical appearance, but in terms of internal psychology too. In Tokyo Cancelled, both the fairy-tale and the gothic conceptions influence the narratives of transformation. In 'The Store on Madison Avenue', for instance, Isabella changes cleanly from store to human to store thanks to some magic Oreos, as per the fairy-tale trope. However, her final failed transformation into 'a thing of stone and flesh, its organs half-formed and leaking, its limbs chafed and mangled' (2005b, p. 148) is clearly gothic-a halted, and horrific, 'becoming'. Isabella's internal (gothic) transformation, absorbing the greed and materialism of the capitalism embodied by the shop, also highlights the risk inherent in a fairytale mode of transformation. It may appear possible to change between forms with one's subjectivity intact but you are always 'infected' by the other. 'The Changeling' is more obviously gothic in its depiction of the 'transformation/mutation' of Fareed who is infected by a plant slowly taking over his body, mutating and changing it and causing him tremendous pain in the process. The final fusion of plant, Fareed and his changeling friend, Bernard, blurs the boundaries between all three 'identities' or 'subjects' as they are 'fused entirely' (2005b, p. 290). Instead of a discrete transformation, there is a mutated joining of three 'subjects' who are becoming one. This transformation contrasts with the changeling Bernard's previous experience of transformation from immortal to mortal to immortal. Throughout the narrative he chooses to 'stay human', which ultimately leads him towards a 'gothic' experience of a unifying 'becoming' transformation and away from the ultimately alienating fairy-tale change that he had 
expected. In each case, the gothic variant becomes dominant and simultaneously highlights the inadequacy of the fairy-tale variant -the dream of fairy-tale transformation is revealed as, at best, empty and, at worst, deceptively dangerous.

We find a similar pattern of dual 'fairy-tale' and 'gothic' engagement with the trope of the animate inanimate in Dasgupta's 'The Doll.' In fairy-tale narratives the inanimate is animated in order to enter into (loving) relationship with it (Pinocchio) or to use its service (the golem). In contrast, the gothic 'creation of life' is for its own sake, to challenge God or the limits of science and the animated being ultimately ends up as a destructive force out of the control of its creator (Frankenstein [1818]). In 'The Doll' we can see the influence of the fairy-tale tope of animating the inanimate for the purpose of relationship as Yukio creates a sentient doll, Yukiko, as his lover. His use of her as an office tool and as a sex object also presents the trope of the animation of the inanimate to perform service. Yukiko's growing independent development, the increasingly destructive dynamic of their relationship, the underlying question of consent and sexual coercion and the ultimate act of 'murder', when Yukio catches his psychiatrist having sex with Yukiko (or Yukiko having sex with the psychiatrist) and destroys her sentient self, are all distinctly gothic. In all these examples, Dasgupta deliberately engages with both gothic and fairy-tale versions of these shared tropes. In doing so, he contrasts them and, in the rejection or defeat of the fairy-tale 'version,' underlines the gothic sensibility of the stories. A fuller investigation of 'The Billionaire's Sleep' will reveal a similar use of the combination and contrast of fairy-tale and gothic elements to underline a fundamentally gothic sensibility to the narrative, showing this to be not only a fairy-tale but specifically a 'gothic fairy-tale.

\section{The gothic fairy-tales of Tokyo Cancelled}

There are multiple fairy-tale elements to 'The Billionaire's Sleep', as already stated: the childless couple longing for children, the existence of benign or positive magic, ${ }^{11}$ and the happy ending of siblings/lovers reunited. There are also various references to specific fairy-tales: the tower and the lover at the bottom of it reference Rapunzel, the kidnap by monster is taken from the Ramayana and the magical sleep and the magically gifted child echo Sleeping Beauty. The fairy-tale influence is clear but there are as many, if not more, gothic tropes that 'infect' the fairy-tale frame: incest, mutation, monstrosity, fratricide, an asylum, family secrets and violent death. The 'tale within a tale' in 'The Billionaire's Sleep' drives home the difference between a true fairy-tale and the disruptive gothic backbone of 'The Billionaire's Sleep'. In the ballad related by Imran, a monster kidnaps a beautiful maiden in order to possess her hair, which is made of pure gold. Her passionately devoted brother seeks to rescue her from the tower by growing a tree up to the window, which is the only point of egress (it is an exceptionally long-term goal). The monster, meanwhile, is concocting a growth potion for her hair so as to be able to harvest it more frequently. Having succeeded, he leaves the potion with her entirely (and inexplicably) unguarded and she throws it from the window onto the sapling that her brother has planted. The brother grabs hold of the growing tree and is carried up to rescue her but the tree continues to grow and they continue upwards. The monster cuts down the tree and it crashes down, crushing the tower and the monster and killing the maiden and her brother. Imran recounts this tale to an audience of eager listeners in his adoptive father's bookshop, all of whom are disappointed by the ending. They ask him, 'Why did they have to die?' His reply is simply to ask, 'They were brother and sister. Were they going to get married and live happily ever after?' (2005b, p. 76). In other words, although it is not 'happily ever after,' it is a fairy-tale ending: closed and with no 'transgressive' implications. The monster is destroyed, the princess is rescued but, in order to avoid incest (moral transgression), there is no wedding but rather a tragic death. The fairy-tale deals in moral absolutes-right and wrong, beautiful and monstrous, evil and good-and 'all characters are either good or bad.' (Propp, 1984, p. $28)^{12}$ Thus, our heroic siblings cannot become an incestuous (bad) couple; they must die. In contrast, the main narrative of 'The Billionaire's Sleep' does not keep to these boundaries. It is not a narrative of clear binaries but of diffusing boundaries and unifying the divided. Imran is simultaneously monster, lover and brother. Sapna is simultaneously maiden, lover and witch. Rajiv plays the role of loving father, abandoning father and gaoler. The incestuous twins not only resist categorisation but, in a very real sense, attempt to break the boundaries that separate them, an aim which is not condemned in the narrative: 'their groins heaved with the effort of penetrating all that separated them, as their bodies hinged extravagantly at their join and exulted in the rightness of lying suspended together in the darkness' (2005b, p. 89). It is not a fairy-tale but a gothic ending. ${ }^{13}$ To understand fully how the ending is gothic, however, we must move beyond the obvious issue of moral transgression and the 'prickly possibilities' (Warner, 1994, p. xvi) of the ending. We must see beyond the tropes of the gothic to its beating heart and examine the issue of desire.

\section{The question of desire}

'The Billionaire's Sleep' confronts us with two forms of 'desire' that are fundamentally juxtaposed. In order to understand the concepts of desire explored in 'The Billionaire's Sleep', we may refer to the work of Gilles Deleuze and Félix Guattari who define desire as a productive process. To comprehend this definition, we must first understand what it is not. In A Thousand Plateaus Deleuze and Guattari present three erroneous conceptions of desire as defined by 'the negative law, the extrinsic rule and the transcendent ideal.' (1987, p. 171). The 'negative law' is the idea of 'Desire as lack' (1987, p. 171), that is, that we, in the wake of the psychoanalytic theories of Jacques Lacan, conceive of desire as being for some determined object that we lack. The 'extrinsic rule' is that 'desire will be assuaged by pleasure,' (1987, p. 171), i.e., pleasure is an 'extrinsic measure' (1987, p. 172) which interrupts or terminates desire. The 'transcendent ideal' is the idea of desire as fantasy: the idea that 'jouissance is impossible, but impossible jouissance is inscribed in desire' $(1987$, p. 171). The idea of impossible 'jouissance' is provided by Lacan in his exploration of the separation between 'expected jouissance' (the transcendent pleasure which our desire seeks to 'obtain') and 'obtained jouissance' (the realisation of our desire). 'Obtained jouissance' never 'lives up to' the 'expected jouissance' and thus the latter is, by definition, impossible (Johnston). These three conceptions of desire all have certain features in common. First, they conceive of desire as having a fixed or known object. Secondly, they are all acquisitive in that they seek to obtain something as the object or end of their desire. Thirdly, they conceive of desire as having an end point of either satiation or disappointment.

For Deleuze and Guattari, desire is not acquisitive but productive; it has no fixed object but rather 'produces' a new state; it does not end but is a constant process. Desire is that which creates connections between 'machines' (the apparently individual components of the world) in order to create not simply the connection itself but the new 'machine', the new reality, formed by this connection. Thus, as Deleuze and Guattari state in AntiOedipus: Capitalism and Schizophrenia, 'desire and its object are one and the same thing: the machine, as the machine of the machine.' (1984, p. 26). The ideal state for Deleuze and Guattari is 
that of the 'body without organs' (or $\mathrm{BwO}$ ), which is a 'connection of desires, a conjunction of flows, a continuum of intensities.' (1987, p. 179). In order to achieve this 'plane of consistency of desire' (1987, p. 172), we must first discard our erroneous conceptions of desire. We must then 'disarticulate' the 'strata' that control and divide the 'body,' which 'nail us down to the dominant reality' (1987, p. 177) rather than encourage the free creation of new ones. Deleuze and Guattari identify these organising 'strata' as 'the organism, significance and subjectification' (1987, p. 176). 'The organism' is the physical body and its organisation. 'Significance' is the act of being 'a signifier and signified, interpreter and interpreted' as part a dominant code of meaning (1987, p. 177). 'Subjectification' refers to the idea of the self as inviolable 'subject'. They make particular mention of the boundaries both of signification and subjectification inherent in the capitalist system, which divides the world into subjects (consumers) and objects (resources), with everything falling onto one side or another of this binary divide: consumer/utilised as society/nature, modern/barbaric, human/animal and so on. For Deleuze and Guattari, 'desire' is both a process of disarticulation of 'strata' and a productive process forging new connections. In 'The Billionaire's Sleep', Dasgupta explores this concept of desire as production and juxtaposes it with a desire-as-lack model of global capitalism.

The first model of desire represented in the story 'The Billionaire's Sleep' is the desire-as-lack lived out by Rajiv and Mira. It is an echo of a fairy-tale model of desire: Rapunzel's parents wish to obtain children; Dame Gothel's desire to obtain eternal life; Rapunzel's desire to obtain freedom and ultimately to obtain a Prince. Brewer suggests, in fact, that it is not simply the 'heroine' or 'hero' of the fairy-tale that wants, but the story itself. He argues that 'the fairy tale...do[es] not study the particular psychology of individual characters as it might be deduced or represented from individuals in everyday experience, but they are nevertheless intrinsically 'psychological'. The psychology is in the structure of the whole tale, representing the experiencing mind in such a way that the reader, whatever his own particularity, can find his own mind and experience of the world indirectly reflection in the story' (1988, p. 24). For Brewer, the whole tale is an emblem of desire, a tale of 'wish-fulfilment' (1988, p. 24) in which the reader seeks to obtain independence and its subsidiaries: peer love and a family of one's own. Importantly, it is a dream of acquisition: desire-as lack. The Ramayana, Rapunzel and Sleeping Beauty do not change the world, rather, they reproduce the same world at the beginning and end of the story. The change is in their own place within this world: a place of increased acquisition. Similarly, conforming to the fairy-tale trope, Rajiv 'lacks' sleep and attempts to acquire it in much the same way that he has acquired wealth and status through the capitalist expansion of his father's business: buying 'sleeping pills, relaxants, anti-anxiety drugs, meditation and hypnosis [...] every kind of therapeutic bed, pillow, earplug, and eyemask.' (2005b, p. 54-55). This acquisitive approach, however, fails him entirely. Rajiv's 'perpetual wakefulness personifies the restless dynamism of capitalism' (Deckhard, 2013, p. 8). His non-sleeping self has become a metaphor of acquisitive capitalism's desire-as-lack and its rhetoric of insatiable constant acquisition. The sterility of the capitalist system in terms of the 'real production' of new realities is emphasised by his impotence. He is able to sleep only when he has 'abandon[ed] the idea of the future' (2005b, p. 89) that is, his attempt to define his own lack and acquire its fulfilment. Rajiv and Mira's desire for a child as 'the fulfilment of their lives' $(2005 \mathrm{~b}, \mathrm{p}$. 55) is another clear example of living with a model of desire-as-lack. The inadequacies of this way of conceiving of desire are emphasised in this instance not by the failure of this desire but by the disastrous consequences of its apparent realisation. Their attempt to 'acquire' a child highlights the insatiable nature of desire-as-lack. Even after Rajiv and Mira have received what they 'lacked', they are not satisfied. The children they had longed for do not fill their lack; they are 'defective'. They are discarded and these discarded 'objects of acquisition' become, in turn, objects of hate and revulsion: 'a curse' to their mother and 'freaks' to their younger brother (2005b, p. 72). The consequences of their desire (as lack) for children, not only makes objects of the children, but ultimately leads to the disintegration of the family, frustration, division, emotional and physical violence, and murder.

A life living out desire-as-lack is ultimately unsatisfying, destructive and self-destructive-a theme which Dasgupta explores in many of the tales in Tokyo Cancelled. ${ }^{14}$ The tales represent many different objects of desire-as-lack. People seek to acquire memories ('The Memory Editor'), money ('The Store on Madison Avenue' and 'The Lucky Ear Cleaner'), a girlfriend ('The Doll'), a husband ('The Mapmaker of Frankfurt'), a child ('The Bargain in the Dungeon'), information ['The Mapmaker of Frankfurt' and 'The Flyover'] and power ['The Mapmaker of Frankfurt']. In doing so, they are never satisfied. In 'The Store on Madison Avenue,' Isabella receives money from her transformation into an exclusive store. She continues her transformations when they are already dangerous; she is caught in an insatiable cycle of greed and the desire to acquire more and more money. As in other tales, this desire-as-lack is destructive to both herself and to others. She is left a suffering half-human, half-thing, the reifying tendencies of desire-as-lack made horrifyingly literal, and Pavel becomes the victim of violence and persecution for her sake. In 'The House of the Frankfurt Mapmaker,' we see how Klaus' desire-as-lack to acquire and utilise knowledge in the creation of his map to 'end all maps' reduces everything and everyone to objects valued on their utility. The fairy-tale's tendency to make characters that 'are typical rather than unique' (Bettelheim, 1976, p. 8) is here traumatically re-imagined-people become types become interchangeable units. The reification is supremely violent, denying the non-objective worth of anything or one, and turning people into nothing more than moving sacks of saleable organs, sexual objects or slave labour. Dasgupta continually repairs to the idea of desire-as-lack as reifying, productive of frustration, alienation and emotional and physical violence and ultimately unsatisfying. It has a posited end-point that always ultimately fails, reigniting the desire-as-lack in an inescapable cycle that is both unfulfilling and inescapably violent.

In 'The Billionaire's Sleep', Dasgupta juxtaposes this inherently violent conception of desire with the productive variant described by Deleuze and Guattari. Imran and Sapna express desire that is unbounded by 'the negative law, the extrinsic rule and the transcendent ideal' (Deleuze and Guattari, 1987, p. 171). In their individual projects and their ultimate union, they both demonstrate the productive nature of desire and its ability to remove or pierce boundaries. Sapna's musical project, which aims to restore the 'correct relationship' (2005b, p. 71) of music and time, is productive desire as a process, disarticulating the artificial boundaries between time and music and producing new connections and new realities. Imran's desire is productive of and expressed through story-telling, which causes all around him to say 'never have we seen such yearning as this.' (2005b, p. 74). The longing that both express has no concrete object, nor any imagined fantasy attached to it, but is instead a project of both destruction of artificial boundaries and confines and a process of creation of the new. Nowhere is this more clearly illustrated than in their desire for each other. The way in which they make love, their groins heaving 'with the effort of penetrating all that separated them' (2005b, p. 89) is not an attempt to acquire the other as sexual object, to fill a lack in the self or to realise a fantasy; it is a process of destroying boundaries and (re)creating a unified 
identity: a 'subversive reunification of alienated spheres: the melding of clones, the cleavage of divided classes and genders, the re-conscionisation of nature-society relations' (Deckhard, 2013, p. 10). They represent a radically different concept of desire as productive: a concept that is reiterated and re-examined throughout Tokyo Cancelled.

'The Changeling' continues this exploration of 'living' productive desire by juxtaposing it to the 'living out' of desire-asfantasy. As Bettelheim notes, this 'desire-as-fantasy' is also intrinsic to the fairy-tale, which he suggests may act as a 'wishfulfilling fantasy' (1976, p. 85). The magical quests of Elvish Knight narratives, for example, with their tales of unconquerable challenges, unanswerable riddles and supernatural love, exemplify this variant of fantastical (and phantasmal) desire. Dasgupta's 'The Changeling' is set in a Paris in which changelings are common but not accepted. Bernard Dusoullier is a changeling, an immortal being who has taken on human form. He is preparing to escape the mortal world for the immortal realm when he meets a dying man, Fareed. As Fareed explains, a 'rare plant is growing inside my body; its flowers are bunching under my skin, compressing my brain and nerves, growing into my organs. Soon they will burst from inside and I will die' (2005b, p. 265). He is engaged in a fantastical quest to find 'a word that will explain these mysteries' (2005b, p. 265) and magically remove his sense of disconnection from his own life and death. Bernard takes over his quest when he becomes too weak but his fantastical desire cannot be met. It is only when he gives up on this acquisitive model of desire-as-fantasy that he finds peace and comes to experience productive desire. After realising that Bernard has failed to find the 'magic' word, Fareed spends the day singing in the garden about life, death and the integral unity of all the things. When Bernard asks him why he is now singing and content, he answers, 'Was it your word? Or was it the disappointment of there not being a word? I don't know but now I am full of words' (2005b, p. 284). Having abandoned his fantasy, his desire for meaning is now organically expressed in a process of production that recognises the 'flow' of the world. The story ends with the death of Fareed and Bernard whose 'body [and soul] fused entirely with that of Fareed' (2005b, p. 290). As they are dying, Fareed declares 'Finally, I do not die alone' (2005b, p. 291), and both he and Bernard die filled with peace. Fareed's desire for meaning in death and communion with another soul and Bernard's desire for a place in the world, have not acquired but created a new reality for both of them, a unification of their flesh and spirit and union with the world (through the plant). Desire-as-fantasy fails here as surely as its counterpart desire-as-lack fails in 'The Billionaire's Sleep' but the stories are not pessimistic. These failed models are rejected in favour of a productive model of desire that is, as I will argue below, inherently gothic.

\section{Gothic desire}

The portrayal of desire as productive and as a process is not a fairy-tale trope. Fairy-tales offer a 'dreaming alternative' (Warner, 1994 , p. xvi) to reality, projecting fantastical lacunas of lack into the readers' own lives. They focus the desire of the protagonists either on outright fantasies or on obtaining 'something' lacked, whether that is a husband, a child, riches, status or even love. Yet despite their 'happy endings', the reader is left, perhaps unconsciously, unsatisfied. There is always the small voice at the back of the mind asking 'what happens after the wedding:' a voice that acknowledges in part the inherent failure of living out desire-aslack. In the gothic, by contrast, such acquisitive desire is more explicitly rejected by its exclusive association with the power-, money-, sex- or blood-hungry villain. These characters appear in the fairy-tale, where the objects of their desire (ill-gotten riches, usurped thrones, power) and their manner of acquisition are condemned. We do not sympathise with Ravana's desire to acquire Sita, nor with his preferred method: kidnap and imprisonment. However, the 'mode' of desire itself is not rejected. The desire to acquire a beloved object (as Rama 'acquires' Sita in his rescue) is not rejected. The gothic offers a different model. The villain is condemned, along with the object of his acquisition (for example, Montoni is condemned for his desire for power, riches and sex), his manner of acquiring it (for Montoni, kidnap, threats, violence and cruelty) and the model of desire itself. In its place, an alternative model of desire is offered-productive desire. Productive desire seeks to destroy barriers, not to obtain what is beyond them but to free itself from the confines of definition, custom and oppression. It has no object to attain but is rather a process of 'becoming'. It has no end point but leaves the next 'chapter' open (not to be read but to be written). It creates new people, new societies, new relations, new configurations, new understandings and new realities. We can see this emphasis even in the seemingly closed narratives of the early gothic romance. The Mysteries of Udolpho (1794) is particularly illustrative in this respect. Its movement 'from here to here' (Kilgour, 1995, p. 113), from the initial starting point in La Vallée to its endpoint in the same geographical location, we see more clearly than in any other gothic tale the idea of the 'new reality' produced at the end of the gothic novel. La Vallée is both the same and qualitatively different. Emily's adventure does not end simply with 'marriage,' nor has her journey been one in search of a husband. Instead, it is one in which her adventures, her experiences, her connections, her new knowledge and, ultimately, her monetary inheritance and increased financial and emotional independence, change both her and the home she returns to. A new reality is both produced and in the process of production: a reality in which Emily's path is self-determined and her marriage one manifestation of her changed self rather than simply the acquisition of a desired other. As we see in Udolpho and throughout gothic production, the gothic:

is the creation through conventional narrative of an anticonventional vision of reality. The fantasies, through such techniques as transformations, metamorphosis, and doubling, reverse conventional assumptions about the relation of self to Other, about good and evil, love and hate, pain and pleasure, objective and subjective, masculine and feminine, cause and effect. (Day, 1985, p. 4)

This dynamic is not fuelled only by the fear and worrying transgressions of the gothic but by a productive element-desire. Tokyo Cancelled highlights the way in which productive desire is an integral part of the gothic process.

Tokyo Cancelled, through its combination and juxtaposition of fairy-tale and gothic modes, highlights both their similarities and differences, combining them to form something that is neither one nor the other but a hybrid form: a gothic fairy-tale. It is a gothic fairy-tale that does not rely merely on bringing the 'latent darkness' of the fairy-tale to the fore in acts of violence and representations of fear and sexual desire. In Tokyo Cancelled we find that that fairy-tale and the gothic mode are not binaries but as related forms on a gradating curve of common features -the fantastic, the unreal, fear and, most importantly for this paper, desire. The disruption of traditional fairy-tale narratives by seemingly 'alien' gothic elements in the stories, however, emphasises the sometimes-irreducible differences between the two forms. In doing so, the novel allies itself with a fundamentally gothic sensibility. The central difference between the two that is highlighted by Tokyo Cancelled is in the conception of desire. While productive desire may appear in fairy-tales, it is over-shadowed by the apparent fulfilment of desire-as-lack and desire-as-fantasy. It 
is, however, not only characteristic of but fundamental to the transgressive project of the gothic. Tokyo Cancelled rejects any other theory of desire and embraces the productive model. In doing so, it rejects the closed happy-ending of the fairy-tale and proffers the truly gothic happy-ending in which the world itself is something other than it was before. It offers a gothic conception of the world with a fairy-tale optimism and in doing so provides a new model of the gothic fairy-tale.

Received: 1 October 2017 Accepted: 5 April 2018

Published online: 24 April 2018

\section{Notes}

1 While Lovecraft's essay is not frequently included in the history of gothic criticism, it offers an early (1927) overview of both gothic and horror fiction.

2 From this point on, I will follow Marina Warner's example in referring to all these collectively as 'fairy-tales'.

3 Both Freud and Eric Jentsch used the animate doll in E.T.A Hoffman's The Sandman as an example of the 'uncanny' (Freud, 1919).

4 This may be either as a point of origin for later 'literary' texts or as a medium of change and progression in an 'original' literary narrative (as we find, e.g., with The Ramayana).

5 I am indebted to Marina Warner's review of numerous fairy-tale tropes in The Beast and the Blonde for many items on this list. Her work is, in turn, partially indebted to the exhaustive work of the Scandinavian school and The Types of Folk-Tale (1928, 1961) of Antti Aarne and Stith Thompson.

6 See Rapunzel, Sleeping Beauty, Snow White narratives (such as those included in Charles Perrault's and the Brothers Grimm's collections) for examples of this trope.

7 In my use of Mysteries of Udolpho, I echo the work done by Williams (1995, p. 256) with additions regarding the additional four categories.

8 I am using the following shorthand to indicate the 'type' of narrative: G-gothic, FT -fairy-tale/folk-tale/myth and D-Dasgupta.

9 I have chosen not to attribute fairy-tales to a single author when they appear in similar forms in multiple collections (such as those by Perrault and the Brothers Grimm). They are based on pre-existing folk-tales and to assign a single 'author' obscures their wider resonances.

10 It must be noted, of course, that the separation of 'gothic' and 'fairy-tale' does not suggest that the 'gothic sensibilities,' particularly as regards specific incidents (such as the consumption of the brides in pie form in Dicken's Bluebeardian 'Captain Murderer'-a story handed down by his nurse), may never be found in fairy-tales, folk-tales and legends etc. and vice versa. There will always be occasions of slippage and the terms attempt to define the dominant trends rather than offer a prescriptive condition.

11 Sapna's power to create plant life, while 'dangerous to unleash' (2005b, p. 69) in the confines of an urbanised space is not, in itself, 'negative' and has positive potential as the government admits with its postulated intention of using her to 'recultivate some of the desert regions.' (2005b, p. 69)

12 In the fairy-tale sources, the maidens Sleeping Beauty, Rapunzel and Sita along with their rescuers and love interests, the Princes and Lord Rama, are unequivocally good. Maleficent, Dame Gothel and the Demon Ravana are cast as villains and unequivocally bad.

13 I will discuss further on the idea of 'closed' endings in the Gothic but to understand the way they differ from a closed fairy-tale ending, we must first investigate the issue of desire.

14 See 'The Store on Madison Avenue', 'The Memory Editor', 'The Doll', 'The House of the Frankfurt Mapmaker' and 'The Flyover'.

\section{References}

Baldick C (1992) 'Introduction'. In: Baldick Chris (ed) The Oxford book of gothic tales. Oxford University Press, Oxford

Bettelheim B (1976) The use of enchantment: the meaning and importance of fairy tales. Vintage Books, New York, NY

Botting F (1996) Gothic. Routledge, London

Brewer D (1988) Symbolic stories: traditional narratives of the family drama in english literature. Longman, London and New York

Dasgupta R (2005a) P.S. ideas, interviews and features. In: Tokyo cancelled. Harper Perennial, London.

Dasgupta R (2005b) Tokyo cancelled. Harper Perennial, London
Davidson HE, Chaudhri A (2003) Introduction. In: Davidson HE, Chaudhri A (ed.) A companion to the fairy tale. Boydell and Brewer, Cambridge

Day WP (1985) In the circles of fear and desire: a study of gothic fantasy. Chicago University Press, Chicago and London

Deckhard S (2013) Uncanny states: global eco-gothic and the world-ecology in Rana Dasgupta's Tokyo cancelled (libre). In: Smith A, Highes W (ed.) Ecogothic. Manchester University Press, Manchester.

Deleuze G, Guattari F (1987) A thousand plateaus. Continuum, London, (trans: Massumi B).

Deleuze G, Guattari F (1984) Anti-oedipus: capitalism and schizophrenia. In: Hurley R, Seem M and Lane HR (eds), Continuum, London.

Dickens C (1860) Captain murderer condensed from nurses stories in all the year round. http://charlesdickenspage.com/captain_murderer.html. Accessed 30 Jan 2018.

Freud S (1919) Unheimlic. English edition: Freud S (1919) The Uncanny (Trans. Alix Strachey 1925, Collected Papers, vol 4, pp 368-407).

Grimm B (1987) 'Rapunzel'. The Complete Fairy Tales (Trans. by Jack Zipes). Vintage Books, London.

Haggerty G (1989) Gothic fiction/gothic form. Pennsylvania State University Press, University Park, PA, London

Johnston A (2012) The forced choice of enjoyment: jouissance between expectation and actualization. Lacan.com. http://www.lacan.com//forced.htm. Accessed 8 Apr 2016.

Kilgour M (1995) The rise of the gothic novel. Routledge, London

Lovecraft HP (2011) Supernatural horror in literature. In: Lovecraft HP (ed) The haunter in the dark. Wordsworth, Ware

Marsh R (2007) The beetle. Wordsworth Editions, Ware

Neumeier B (1996) Postmodern gothic: desire and reality in Angela Carter's Writing. In: Sage V, Smith AL (eds) Modern gothic: a reader, Manchester University Press, Manchester

Propp V (1984) Theory and history of folklore. In: Martin AY and Martin RP (eds), Manchester University Press, Manchester.

Punter D (1996) The literature of terror: a history of gothic fictions from 1765 to the present day, vol 1, 2nd. Longman, London

Radcliffe A (1795) The mysteries of Udolpho, vol. 1-4. G.G. and J. Robinson, London

Seem M (1984) Introduction to anti-oedipus: capitalism and schizophrenia. Continuum, London

Simpson H, Carter A (2006) The bloody chamber: an introduction. Vintage, London

Varma D (1957) The gothic flame. Arthur Barker Ltd, London

Warner M (2002) Fantastic metamorphoses, other worlds. Oxford University Press, Oxford

Warner M (1994) From the blonde to the beast. Chatto and Windus, London

Williams A (1995) Art of darkness: a poetics of Gothic. University of Chicago Press, Chicago; London

\section{Data availability}

Data sharing is not applicable to this article as no datasets were analysed or generated.

\section{Additional information}

Competing interests: The authors declare no competing interests.

Reprints and permission information is available online at http://www.nature.com/ reprints

Publisher's note: Springer Nature remains neutral with regard to jurisdictional claims in published maps and institutional affiliations.

Open Access This article is licensed under a Creative Common Attribution 4.0 International License, which permits use, sharing, adaptation, distribution and reproduction in any medium or format, as long as you give appropriate credit to the original author(s) and the source, provide a link to the Creative Commons license, and indicate if changes were made. The images or other third party material in this article are included in the article's Creative Commons license, unless indicated otherwise in a credit line to the material. If material is not included in the article's Creative Commons license and your intended use is not permitted by statutory regulation or exceeds the permitted use, you will need to obtain permission directly from the copyright holder. To view a copy of this license, visit http://creativecommons.org/ licenses/by/4.0/

(C) The Author(s) 2018 